\title{
Agent Banking And Poverty Reduction In Benue State, Nigeria
}

\author{
David Terfa Akighir \\ Department of Economics, Benue State University, Makurdi, Nigeria
}

Tyagher T. Jacob

First Bank Limited, Makurdi Branch, Benue State Nigeria

Aaron Ateata

University of Mkar, Benue State, Nigeria

\begin{abstract}
The study investigated the impact of agent banking on poverty reduction in Benue State, Nigeria. The study is hinged on the agency theory, risk management theory, the regulatory dialectic theory and the basic needs theory. Focusing on the agent banking activities of the First bank PLC, the study used the Taro Yammene's formula to select 199 agents for investigation. Questionnaire was used for data collection but only 185 copies of the questionnaire were retrieved for analysis. The study employed descriptive tools such as tables and percentages and paired $t$ test as well as Foster, Greer and Thornbecke (FGT) index. Also, a logit regression model was employed to ascertain whether or not agent bank has the probability of reducing poverty in Benue State. The study found that engaging in agent banking has the probability of reducing poverty in Benue State which is typically an agrarian state with high poverty incidence among highly unbanked population. Agent banking in this unbanked State where only 11 local government areas out of 23 local government areas have the presence of banks has the potential of increasing financial inclusion and enhancing financial literacy. With the presence of agent banking in the state, it will enhance business sustainability and facilitate financial transactions. These will increase economic activities and increase employments and reduce poverty. Given the potentials of agent banking for socio-economic development in the state, it is recommended that financial literacy awareness should be created so that rural population who have long lived unbanked to accept banking services via the agent banking. Also, banks operating in the state should leverage on the opportunity of agent banking to penetrate the rural population with a view to achieving financial inclusion in line with the CBN's revived National Financial Inclusion Strategy (NFIS) which places implementation focus on women, rural areas, youth, Northern Nigeria and MSMEs to achieve 95\% financial inclusion rate by 2024.
\end{abstract}

Keywords: Agent Banking, Benue State, Foster, Greer Thornbecke (FGT) Index, Pair t-test, Poverty Reduction, and Logit Regression 
Akighir, D. T., \& Jacob, T. T., \& Ateata, A. (2020) Agent Banking And Poverty Reduction In Benue State, Nigeria. Advances in Social

\section{INTRODUCTION}

The provision of affordable financial services to the rural population has been a key component of development strategy for the past decades in many countries. Direct intervention in rural banking and financial markets through targeted credit programmes, interest subsides and other government controls became widespread in the post-independence era, when Keynesian economic thinking inspired public intervention as a development strategy (Mohammed, 2005).

In every economy, the activities of the financial institutions are regulated by the Apex bank to ensure smooth and functional financial operations. The aim of every central bank is to achieve financial inclusion and reduce financial dualism for ease of economic regulation. In developing countries, however, the formal and informal financial sectors co-exist; in Nigeria for instance, the country has an adult population of 84.7 million, of which only $30 \%$ of them are banked. This suggests that majority of Nigerians do not benefit from banking services but largely operate in the informal financial system (Lekanwj 2016).

Benue State is one of the thirty-six states of Nigeria, the State has twenty-three (23) Local Government Areas, however, banks are found in only eleven (11) Local Government Areas which are mostly in their headquarters; the remaining twelve (12) Local Government areas do not have access to any banking services. This worrisome situation makes it impossible for the rural dwellers in such local governments to access formal banking services.

With the successful introduction and implementation of the cashless policy, which culminated in Mobile Money Operation (MMO) in the country, the Central Bank of Nigeria (CBN) is now targeting the unbanked segments of the society with the introduction of agent banking. As a result, some banks operating within the state have started practicing agent banking in the state. Given this development, the question that arises is that; has agent banking increase financial inclusion and has reduced poverty among the rural dwellers in Benue State? The answer to this question requires empirical investigation.

The objective of this study is therefore, to investigate the impact of agent banking on poverty reduction in the rural areas of Benue State focusing on agent banking efforts of the First Bank PLC in Benue State.

\section{Conceptual Clarification}

Under this section, the concepts of agent banking and poverty reduction are conceptualized.

\section{Concept of Agent Banking}

The CBN (2017), defines agent bank as the provision of financial services to customers by a third party (Agent) on behalf of a licensed deposit Financial Institution (FI) and/or Mobile Money Operators (MMO). According to Ogah, Okwe and Adeoye (2015), agent banking is the delivery of financial services outside conventional bank branches, often using non-bank retail agents and relying on technology, such as card readers, point-of-sale (POS) terminal or mobile phones for real time transaction processing. A banking agent is a retail or postal outlet contracted by a licensed deposit taking financial institution or a mobile money operator to provide a range of financial services to customers. They explained that the novel banking system is aimed at enhancing financial 
inclusion, as banking agents are expected to act as delivery channels and to offer banking services in a cost effective manner.

Thus, an agent is an entity that is engaged by a financial institution to provide specific financial services on its behalf using the agent's premises. The CBN (2017) has categorized agents into 3 simple categories; namely,

Super-Agent: A super-agent is an agent that has been contracted by the principal and thereafter may subcontract other agents in a network while retaining overall responsibility for the agency relationship (CBN, 2017).

Sole Agent: A Sole agent is an agent who does not delegate powers to other agents but assumes agency relationship/responsibility by himself (CBN, 2017).

Sub-Agent: A sub-agent is a person to whom some or all aspects of the agent banking have been delegated. An agent bank relies on technology such as Card reading Point Of Sales (POS) terminals for real time transaction processing (CBN, 2017).

According to CBN (2017), the following are the functions of the agent bank, collect cash deposit from customers of both their principal financial institution and other banks; Pay cash on behalf of customers of their principal financial institution and other banks; make cash transfers to customers of their financial institution and other banks; make cash transfer from customers of their principal financial institution and other banks; make bill payments and purchase airtime on behalf customers of their principal financial institution and other banks; and act as correspondence and pick up point for customers of their principal financial institution.

There are existing bank customers in remote areas who already use banking services and those that are yet to use any form of formal banking services (unbanked). The agency banking strategy is meant to bring banking close to them through the use of agents to provide branchless bank services in their neighborhood thereby reducing travel time and expenses. The agents are under the direct supervision of the FIs that appoints them. The FIs has the power to set limits on their transactions, approve all allowable charges for them and also delist them when they are seen to be involved in illicit activities. The banks are also obliged to deploy appropriate technologies for the agent use (CBN, 2017).

\section{Agent Eligibility}

According to CBN (2017), an agent is eligible upon the fulfilment of the following conditions: The individual must have been in commercial activities for at least 12 months and must be a going concern; the prospective agent must be a registered entity, public entity or a trust; a non-profit making establishment cannot be engaged in agency banking; an organization subject to regulation under any law will need the approval of the regulatory authority to engage in agency banking; a business entity that has been classified as a non performing borrower by any financial institution in the last 12 months cannot be engaged in agency banking; the prospective agent is to provide appropriate infrastructure and human resources to provide the service required and the prospective agent should not have any record of criminal activities. 
Akighir, D. T., \& Jacob, T. T., \& Ateata, A. (2020) Agent Banking And Poverty Reduction In Benue State, Nigeria. Advances in Social Sciences Research Journal, 7(5) 213-229.

\section{Advantages of Agency Banking}

Some banks are already adopting agency banking as a channel for conducting financial transactions to attract existing customers as well as acquire new customers in semi urban/rural areas where banking activities are not available. Other reasons banks are adopting Agent Banking strategy includes:

1. Reduction in the cost of ATM services to their customer. Remote on Us (RoU) ATM cost has been a major concern for most old generation banks especially one that pioneered ATM service in Nigeria. The bank spent over \#4billion in 2014 in settling other banks on who's ATMs their customers' cards are used. The figure reduced to \#3billion in 2015 as a result of CBN policies.

\section{Support for CBN financial inclusion strategy}

3. Substitute for loss making branches or low profitability locations or support for virgin and unbanked locations (CBN, 2017).

\section{Concept of Poverty Reduction}

According to Ahmed (1993), poverty reduction refers to efforts aimed at reducing the magnitude of poverty defined in terms of the proportion of population living below poverty line. To Abdullahi (1999), poverty reduction is a situation where specific manifestations of poverty are systematically reduced resulting to a short term condition. However, Ajakaiye (2000) notes that poverty reduction does not only refers to a short term relief and satisfaction of basic needs, but also development of strategies for increasing the long run goals. Ogwumike (2002) posit that the strategies should be in form of policies of government that intend to broaden the opportunities available to the poor and ensure that every citizen has access to the basic needs of life such as food, shelter, water, health, education and minimum income.

Thus, poverty reduction involves improving the living standard or condition of the poor using policies and programmes, aimed at broadening the opportunities available to the poor and ensuring that every citizen has access to the needs of life such as food, services, nutrition, basic education and medical care services.

\section{THEORETICAL REVIEW}

This theory is anchored on the Agency theory, risk management theory, the regulatory dialectic theory and the basic needs theory.

\section{a. Agency Theory}

Agency theory as developed by Stiglitz in 1989 to justify the government goals of safety and protection. Regulatory intervention is required for the protection of public savings when it is threatened by the behavior of financial institutions. The main trust of this theory is that, government agencies must be present to supervise and limit the excesses of financial institutions toward customer safety and protection. The theory also focuses attention on the problems of hidden actions and hidden information, what Sinkey (1992) called "moral hazard" and "adverse selection" respectively, to set strategies in order to circumvent the problems and ensure safety and confidence of savers in the system. 


\section{b. Risk management Theory}

Risk management theory, developed by Davis in 1991 to explain why regulators are concerned with monitoring and supervising the management of risks, such as liquidity and credit due to the effect of mismanagement by major banking financial institutions, of the amount and timing of such risks on other parts (layers) of the financial system. The main thrust here is, the level of risk in the system, the volatile nature of financial sector requires an ultra-sound to ensure risks are minimal and participants bear less burden in the financial system (Currie, 2003).

\section{c. The regulatory dialectic Theory}

The regulatory dialectic theory is based on the work of Kane in 1981. This theory strives to explain the ongoing struggle between the regulators and financial institutions. The regulators attempt to impose constraints on the financial system (interest rate, product, geographic control etc). The institutions who tend to be driven by profit or wealth maximization motives, attempt to circumvent the restrictions because they consider such as structural arbitrage. This process (contagion), create cost and benefit analysis for government officials leading to reactive adjustment in operative codes of regulation. In a nutshell, Kane's theory examine the struggle engage by both the regulators and the financial institutions to achieve their goals, in the process some adjustment emerged (exogenously) leading to regulatory changes toward financial or monetary stability.

\section{d. The Basic Needs Theory}

The basic needs approach was introduced by the international labour organization in 1976, mainly in reaction to prevalent modernization -and structuralism-inspired development approaches, which were not achieving satisfactory results in terms of poverty alleviation and combating inequality in developing countries (Ogwamuke, 1991). The proponents of the Basic Needs theory advocate for government intervention in establishing patterns of demand and supply in order to redistribution income and assets among the various classes of people in the society with a view to increasing the standard of living in the society. The basic needs theory emphasizes the minimum level of consumption 'basic need' of not just food, water, clothing and shelter, but also sanitation education and health care (Oladeji and Abiola, 2000).

\section{Theoretical Linkage}

Both the agency theory, risk management theory and the regulatory dialectic theory try to explain how financial regulatory institutions in an economy always evolve some regulatory measures on the operating financial institutions with a view to ensuring the smooth flow of financial transactions in an economy. The basic needs theory on the other hand, posits that with government interventions, incomes can be redistributed to enhance consumption of the basic needs of life such as food, clothing, education, shelter and medical care among the poor which tend to improve their standard of living. These theories have adequately explained the dynamics of the agency banking whereby the CBN as the apex financial regulatory body in Nigeria has put in place some regulations that govern the actions of the financial institutions licensed to operate the agency banking in Nigeria and the agents alike. The aim is to ensure that financial institutions and the agents strictly operate within the stipulated guidelines so as to achieve the predetermined objectives of the policy which include financial inclusion, cashless policy and economic growth and development of the Nigerian economy. 
Akighir, D. T., \& Jacob, T. T., \& Ateata, A. (2020) Agent Banking And Poverty Reduction In Benue State, Nigeria. Advances in Social

\section{Study Area}

\section{METHODOLOGY OF THE STUDY}

The study area of this study is Benue State; the State is one of the North central states in Nigeria with a population of about 4,253,641 based on the 2006 census. It is inhabited predominantly by the Tiv, Idoma and Igede peoples, who speak Tiv, Idoma, and Igede languages, respectively. Its capital is Makurdi. Benue is a rich agricultural region; the popularly grown crops includes; sweet potatoes, cassava, soya bean, guinea corn, yams, sesame, rice, and groundnuts.

The State is predominantly agrarian where more than 70 per cent of the working population is involved in agricultural activities. Thus, with the vast agricultural activities and production, the State is called 'The Food Basket of the Nation'. However, agricultural mechanization is very low in the State due to financial challenges. As a result, most of the farmers are smallholder farmers.

The State is made up of twenty-three local government areas. For administrative convenience, Benue State is divided into three geographical areas, namely; zone A (Katsina-Ala, Konshisha, Kwande, Logo, Ukum, Ushongo and Vandeikya local governments); Zone B (Gboko, Buruku, Tarka, Guma, Gwer East, Gwer West, and Makurdi local governments); and Zone C (Ado, Agatu, Apa, Obi, Ogbadibo, Ohimini, Oju, Okpokwu, and Otukpo local governments).

\section{Population and Sampling Technique}

The population of this study comprises the banking agents of the First Bank Plc in Benue State and the users of the platforms of these agents for banking services in Benue State. Table1 shows the Agents of First Bank Plc in Benue State as at 31 ${ }^{\text {st }}$ January, 2020. 
Table 1: Number of First Bank Plc Agents in Benue State

\begin{tabular}{|c|c|c|}
\hline $\mathbf{S} / \mathbf{N}$ & Local Government Areas & Number of Agents \\
\hline 1 & Ado & 8 \\
\hline 2 & Agatu & 6 \\
\hline 3 & Apa & 7 \\
\hline 4 & Buruku & 10 \\
\hline 5 & Gboko & 33 \\
\hline 6 & Guma & 10 \\
\hline 7 & Gwer East & 9 \\
\hline 8 & Gwer West & 5 \\
\hline 9 & Katsina-Ala & 13 \\
\hline 10 & Konshisha & 17 \\
\hline 11 & Kwande & 42 \\
\hline 12 & Logo & 5 \\
\hline 13 & Makurdi & 84 \\
\hline 14 & Obi & 7 \\
\hline 15 & Ogbadibo & 15 \\
\hline 16 & Ohimini & 1 \\
\hline 17 & Oju & 2 \\
\hline 18 & Okpokwu & 19 \\
\hline 19 & Otukpo & 52 \\
\hline 20 & Tarka & 4 \\
\hline 21 & Ukum & 3 \\
\hline 22 & Ushongo & 13 \\
\hline \multirow[t]{2}{*}{23} & Vandeikya & 30 \\
\hline & Total & 395 \\
\hline
\end{tabular}

Source: First Bank Plc, Makurdi Branch 2020.

The above table shows that there are 395 agents of First Bank Plc in Benue State across all the 23 local governments of the State.

\subsection{Sample Size Determination}

The study used the Taro Yammene's formula given as follows to determine the optimum sample size for the study.

$n=\frac{N}{1+N\left(e^{2}\right)}$

Where $n$ is the sample size, $e$ is the level of significance, $N$ is the population which is 395 agents of First Bank Plc in Benue State.

Using the formula, that is , $n=\frac{395}{1+395\left(0.05^{2}\right)}=199$

Therefore, the optimal sample size for agents of First Bank Plc in Benue State is 199 agents.

In order to avoid biasedness and ensure a fairly representation in the sampling procedure, the Boyce's allocation was utilized as shown in Table 2. 
Akighir, D. T., \& Jacob, T. T., \& Ateata, A. (2020) Agent Banking And Poverty Reduction In Benue State, Nigeria. Advances in Social Sciences Research Journal, 7(5) 213-229.

Table 2: Boyce's Allocation of the Sampled Agents in the 23 LGAs of Benue State

\begin{tabular}{|c|c|c|c|c|}
\hline S/N & $\begin{array}{|ll|}\text { Local Government } \\
\text { Areas }\end{array}$ & $\begin{array}{l}\text { Number of } \\
\text { Agents }\end{array}$ & Workings & Sample \\
\hline 1 & Ado & 8 & $8 / 395 * 199$ & 4 \\
\hline 2 & Agatu & 6 & $6 / 395 * 199$ & 3 \\
\hline 3 & Apa & 7 & $7 / 395 * 199$ & 4 \\
\hline 4 & Buruku & 10 & $10 / 395 * 199$ & 5 \\
\hline 5 & Gboko & 33 & $33 / 395 * 199$ & 17 \\
\hline 6 & Guma & 10 & $10 / 395 * 199$ & 5 \\
\hline 7 & Gwer East & 9 & 9/395*199 & 5 \\
\hline 8 & Gwer West & 5 & $5 / 395 * 199$ & 3 \\
\hline 9 & Katsina-Ala & 13 & 13/395*199 & 7 \\
\hline 10 & Konshisha & 17 & $17 / 395 * 199$ & 9 \\
\hline 11 & Kwande & 42 & $42 / 395 * 199$ & 21 \\
\hline 12 & Logo & 5 & $5 / 395 * 199$ & 3 \\
\hline 13 & Makurdi & 84 & $84 / 395 * 199$ & 42 \\
\hline 14 & Obi & 7 & $7 / 395 * 199$ & 4 \\
\hline 15 & \begin{tabular}{|l|} 
Ogbadibo \\
\end{tabular} & 15 & $15 / 395 * 199$ & 8 \\
\hline 16 & Ohimini & 1 & $1 / 395 * 199$ & 1 \\
\hline 17 & Oju & 2 & $2 / 395 * 199$ & 1 \\
\hline 18 & Okpokwu & 19 & 19/395*199 & 10 \\
\hline 19 & Otukpo & 52 & $52 / 395 * 199$ & 26 \\
\hline 20 & Tarka & 4 & $4 / 395 * 199$ & 2 \\
\hline 21 & Ukum & 3 & $3 / 395 * 199$ & 2 \\
\hline 22 & Ushongo & 13 & $13 / 395 * 199$ & 7 \\
\hline 23 & Vandeikya & 30 & $30 / 395 * 199$ & 15 \\
\hline & Total & 395 & & 199 \\
\hline
\end{tabular}

Source: Author's Computations

Also, 20 customers who use the banking platforms of the agents were selected in each of the 23 LGAs of the State. This gives 460 customers. Thus, the total sample size for this study comprises 199 agents and 460 customers, summing up to 659 respondents.

The study combined simple random sampling technique with proportionate sampling technique which is a non-probability sampling technique. The 199 agents will be randomly selected. This sampling technique offers every member of the population the equal opportunity of been included in the sample. This randomization reduces the tendencies of biases and ensures representativeness (Ngutsav \& Akighir, 2016). On the other hand, the 460 customers were proportionately selected with the assistance of the agents who have access to the customers. The sources of data for this study are basically two sources, namely; primary and secondary sources. The primary sources are concerned with information that were sourced from the questionnaire, oral interviews and Focused Group Discussions; while the secondary data in this study has to do with data from the records of First Bank Plc on Agency Banking and the records of the Agents on their transactions with the customers, specifically, on the volume and the value of financial transactions and the type of transactions. 


\section{METHOD OF DATA ANALYSIS}

The study used both descriptive and inferential statistical tools as well as logistic regression model to analysis the data collected. In addition, the Foster Greer Thorbecke (FGT) poverty indices were used to ascertain the poverty profile of the agents and customers before and during the agency banking.

\section{Logistic Regression}

A logit regression model is commonly used for poverty studies (Yusuf, Adesanoye and Awotide; 2008, Imran, Shahnawazi and Abo; 2009 and Akighir, Ngutsav, and Asom; 2011). In logit model, the endogenous variable is dichotomous or dummy variable with (1) representing the household as poor and (0) if the household is not poor. The logit model is suitable for poverty studies because by its binary nature, the respondents are classified into poor and non-poor. The general form of the model is given as;

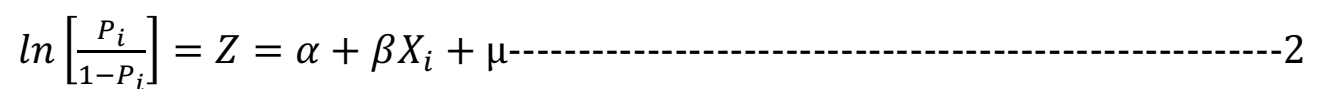

$\mathrm{Z}=$ Denotes the dichotomy qualitative variable, poor/non-poor;

$\mathrm{X}_{\mathrm{i}}=$ Denotes the characteristic vector(s) of households; and

$\mu=$ is the error term.

For the purpose of this study, the logit model for the agents is specified as follows;

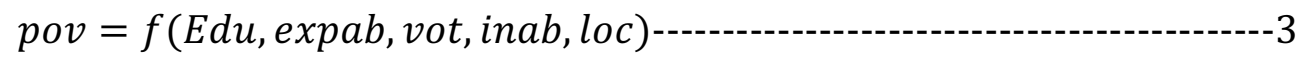

Where

pov $=$ poverty status (dependent variable) calculated using the World Bank poverty line of 1.9 dollars (i.e. at N305 per \$) per day. Thus, if an agent earns less than N579.5 per day, he/she is classified poor and any agent that earns above N579.5 per day is classified non-poor. If poor $=1$ and non-poor $=0$

Edu is the level of education of an agent, expab is the experience of agent in agency banking, Inab is income earned from agency banking activities, Vot is the volume of transactions in a day Loc is the location of the agent (if in rural 1 and 0 if urban)

The stochastic form of the model is expressed as follows;

$$
p o v=\alpha_{0}+\alpha_{1} e d u+\alpha_{2} \operatorname{expab}+\alpha_{3} \text { inab }+\alpha_{4} v o t+\alpha_{5} l o c+\mu----------4
$$

$\alpha_{0}=$ is the intercept of the mode;

$\alpha_{1}-\alpha_{5}=$ are the parameter to be estimated in the model

The logit model was estimated using the maximum likelihood estimation technique.

\section{Foster, Greer and Thornbecke (FGT) Index}

This method was developed by Foster, Greer and Thornbecke in 1984. The method subsumes the Headcount ratio and poverty measurement of the population below the poverty line; while the poverty gap measures the depth of poverty (Anyanwu, 1997). 
Akighir, D. T., \& Jacob, T. T., \& Ateata, A. (2020) Agent Banking And Poverty Reduction In Benue State, Nigeria. Advances in Social Sciences Research Journal, 7(5) 213-229.

The headcount ratio is stated as follows:

$H=\frac{Q}{N}$ .5

Where $H$ is headcount ratio with values ranging from 0 to 1 ; the closer the value to 1 , the higher the proportion of people below the poverty line.

$Q$ is the number of agents and customers below the poverty line, and $N$ is the total number of agents and customer sampled for study.

According to Oyedeji and Adebayo (2013), the poverty gap is measured as follows:

$P_{\alpha}=\frac{1}{N} \sum_{j=1}^{N}\left(\frac{Z-Y_{I}}{Z}\right)^{\alpha}$

Where $P_{\alpha}$ is the poverty gap, $Z$ is the poverty line, $Y_{i}$ is income of the ith household in poor population, $\alpha$ the FGT parameter with values from 0,1 and 2 and $N$ is the total number of agents and customers studied.

\section{Empirical Results}

This section presents the poverty analysis of the agents before and during the agent banking. The information about the demographics of the agents were collected and presented in the following table.

Table 3: Demographic Information of the Agents

\begin{tabular}{lll}
\hline Items & Frequency & Percentage (\%) \\
\hline Sex & 120 & 64.86 \\
Male & 65 & 35.14 \\
Female & $\mathbf{1 8 5}$ & $\mathbf{1 0 0}$ \\
Total & & \\
Age & 96 & 51.89 \\
18-30 years & 66 & 35.68 \\
31 -50 years & 23 & 12.43 \\
Above 50 years & $\mathbf{1 8 5}$ & $\mathbf{1 0 0}$ \\
Total & & \\
Marital Status & 28 & 15.14 \\
Married & 113 & 61.08 \\
Single & 18 & 9.73 \\
Divorced & 26 & 14.05 \\
Widow/widower & $\mathbf{1 8 5}$ & $\mathbf{1 0 0}$ \\
Total & & \\
Level of Education & 0 & 0 \\
Primary Education & 09.19 \\
Secondary Education & 128 & 30.81 \\
Tertiary Education & 57 & $\mathbf{1 0 0}$ \\
Total & $\mathbf{1 8 5}$ &
\end{tabular}

Source: Field Survey, 2020 
It is evident from Table 3 that males are more involved in agent banking, this may be due to the fact that male folk in developing countries are mostly heads of the families who strive harder to fend for other family members. Also, the table reveals that people from the age brackets of 18-50 years are mostly involved in agent banking, this may be ascribed to high unemployment level in Nigeria and Benue state in particular where many graduates do not have access to paid employments and are largely engaged in self-employments. Furthermore, the table indicates that single people are more into agent banking. This may not be unconnected to the fact that in Nigeria and Benue state, young boys must struggle before getting married due to high poverty incidence in the state. Lastly, it can be seen from the table that people who have secondary school certificate are more into agent banking. This may be attributable to the fact majority of the people in Benue state upon graduating from secondary school do not have sponsorships to advance their learning careers due to high poverty incidence and the readily available alternative is trading.

\section{Distribution of the Agents by Total Income per Annum}

The Table 4 presents the total income of sampled agent in the study area before and during agent banking activities.

Table 4: Income of Agents Before and During Agent Banking

\begin{tabular}{lllll}
\hline Income (N) & \multicolumn{2}{l}{ Before Agent Banking } & \multicolumn{2}{c}{ During Agent Banking } \\
\cline { 2 - 5 } Below 200,000 & Frequency & Percentage (\%) & Frequency & Percentage (\%) \\
$\mathbf{2 0 1 , 0 0 0 - 5 0 0 , 0 0 0}$ & 102 & 11.35 & 14 & 7.57 \\
Above 5000,000 & 62 & 55.14 & 67 & 36.22 \\
Total & 33.51 & 104 & 56.22 \\
Paired t-test & $7.87^{* *}$ & $\mathbf{1 0 0}$ & $\mathbf{1 8 5}$ & $\mathbf{1 0 0}$ \\
\hline
\end{tabular}

Source: Field Survey, 2020

** Denotes $5 \%$ level of significance

The table shows the average incomes of agents before and during the agent banking activity. It is evident from the table that before the agents got involved in agent banking, majority of the agents were earning average income ranging from $\mathrm{N} 201,000-\mathrm{N} 500,000$ but given their engagements in the agent banking majority of the agents earned average income of N500,000 and above. To ascertain whether or not there exist a significant difference in the average earns of the agents before and during the agent banking business, the paired t-test was computed and the results revealed that the paired t-test value of 7.87 is statistically significant at 5\% level of significance. This implies the rejection of the null hypothesis and the acceptance of the alternative hypothesis, meaning that there is statistically significant difference in average earnings of the agents before and during the agent banking activity.

Furthermore, the multi-dimensional approach to poverty was used and information concerning the house types of the agents before and during the agent banking were collected and presented in the following table. 
Akighir, D. T., \& Jacob, T. T., \& Ateata, A. (2020) Agent Banking And Poverty Reduction In Benue State, Nigeria. Advances in Social

Table 5: Distribution of the Sampled Agents by House Type

\begin{tabular}{|c|c|c|c|c|}
\hline \multirow{3}{*}{$\begin{array}{l}\text { House type } \\
\text { Zinc and cemented }\end{array}$} & \multicolumn{2}{|c|}{ Before Agent Banking } & \multicolumn{2}{|c|}{ During Agent Banking } \\
\hline & Frequency & Percentage (\%) & Frequency & Percentage (\%) \\
\hline & 29 & 15.68 & 79 & 42.70 \\
\hline $\begin{array}{l}\text { Zinc and not } \\
\text { cemented }\end{array}$ & 45 & 24.32 & 58 & 31.35 \\
\hline $\begin{array}{l}\text { Thatched and } \\
\text { cemented }\end{array}$ & 59 & 31.89 & 22 & 11.89 \\
\hline $\begin{array}{l}\text { Thatched and not } \\
\text { cemented }\end{array}$ & 52 & 28.11 & 26 & 14.05 \\
\hline Total & 185 & 100 & 185 & 100 \\
\hline Paired t-test & $6.89 * *$ & & & \\
\hline
\end{tabular}

Source: Field Survey, 2020

** Denotes 5\% level of significance

The table reveals that before the agent banking, majority of the respondents were living in thatched and cemented houses as well as thatched and not cemented houses but with their engagements in the agent banking majority of the respondents and living in zinc and cemented as well as well as zinc and not cemented houses. The paired t-test indicates a value of 6.89 which is statistically significant at $5 \%$ level of significance which suggests that there is a significant difference in the housing conditions of the respondents before and during the agent banking periods.

Again, using the multi-dimensional approach, information on the number of times the respondents take meals in a day before and during the agent banking were collected and the results are presented in the following table.

Table 6: Distribution of the Sampled Agents by the Number of Meals taken per Day

\begin{tabular}{lllll}
\hline & \multicolumn{2}{l}{ Before Agent Banking } & \multicolumn{2}{l}{ During Agent Banking } \\
\cline { 2 - 5 } No. of Meals & Frequency & Percentage (\%) & Frequency & Percentage (\%) \\
Three times & 35 & 18.92 & 75 & 40.54 \\
Two times & 72 & 38.92 & 84 & 45.41 \\
Once a day & 78 & 42.16 & 26 & 14.05 \\
Total & 185 & 100 & 150 & 100 \\
Paired t-test & $5.69^{* *}$ & & & \\
\hline
\end{tabular}

Source: Field Survey, 2020

** Denotes $5 \%$ level of significance

Table 6 shows the number of meals taken by the respondents before and during the agent banking. It is evident from the table that before their involvement in agent banking activity, majority of the respondents were taken meals once and twice a day but their engagements in the agent banking, majority of the respondents take meals twice and thrice a day. The paired t-test value of 5.69 is statistically significant at $5 \%$ level of significance. This suggests that there is a significant difference in the number of times the respondents take meals before and during the agent banking epochs. In furtherance with the multidimensional approach to assessing the impact of agent banking on the poverty conditions of the respondents, data on the number of times the respondents purchase new 
clothes in a year was collected before their involvement in agent banking and during agent banking and the results are presented in the following table.

Table 7: Distribution of the Sampled Agents by Numbers of clothes purchase per year

\begin{tabular}{|c|c|c|c|c|}
\hline \multirow{2}{*}{$\begin{array}{l}\text { Number of } \\
\text { cloths }\end{array}$} & \multicolumn{2}{|c|}{ Before Agent Banking } & \multicolumn{2}{|c|}{ During Agent Banking } \\
\hline & Frequency & Percentage (\%) & Frequency & Percentage (\%) \\
\hline Non a year & 6 & 3.24 & 0 & 0 \\
\hline Once a year & 72 & 38.92 & 21 & 11.35 \\
\hline Two times & 43 & 23.24 & 74 & 40.00 \\
\hline $\begin{array}{l}\text { Three times and } \\
\text { above }\end{array}$ & 64 & 34.59 & 90 & 39.46 \\
\hline $\begin{array}{l}\text { Total } \\
\text { Paired t-test }\end{array}$ & $\begin{array}{l}185 \\
4.87 * *\end{array}$ & 100 & 185 & 100 \\
\hline
\end{tabular}

Source: Field Survey, 2020

** Denotes $5 \%$ level of significance

Table 7 provides information about the number of times the respondents purchase new clothes before and during the agent banking era. It can be seen from the table that before the agent banking, majority of the respondents were buying clothes once and thrice a year but with their engagements with agent banking, majority are buying new clothes twice and three times and above. In order to ascertain whether or not a difference exist between these two periods, a paired t-test was computed which yielded a value of 4.87 that is statistically significant at 5\% level of significance. This implies that there is a significant difference in the clothing situation of the respondents before and during the agent banking epochs.

In continuation with the multidimensional approach, information regarding access to medication by the respondents before and during the agent banking were collected and presented in the following table.

Table 8: Distribution of the Sampled Agents by type of Medical Facilities

\begin{tabular}{lllll}
\hline Medical Facility & \multicolumn{2}{l}{ Before Agent Banking } & \multicolumn{2}{l}{ During Agent Banking } \\
\cline { 2 - 5 } & Frequency & Percentage (\%) & Frequency & Percentage (\%) \\
Traditional & 28 & 15.14 & 6 & 3.24 \\
$\begin{array}{l}\text { Pharmacy/ } \\
\text { chemist }\end{array}$ & 95 & 51.35 & 43 & 23.24 \\
Clinic & & & & \\
Hospital & 41 & 22.16 & 16 & 8.65 \\
Total & 21 & 11.35 & 120 & 64.86 \\
Paired t-test & $\mathbf{1 8 5}$ & $\mathbf{1 0 0}$ & $\mathbf{1 8 5}$ & $\mathbf{1 0 0}$ \\
\hline
\end{tabular}

Source: Field Survey, 2020

** Denotes $5 \%$ level of significance

Table 8 shows the medical facilities visited by the respondents in periods of ailments before and during the agent banking. The table reveals that before their engagements in agent banking, majority of the respondents were visiting pharmacy/chemist and clinics during periods of ailments 
Akighir, D. T., \& Jacob, T. T., \& Ateata, A. (2020) Agent Banking And Poverty Reduction In Benue State, Nigeria. Advances in Social Sciences Research Journal, 7(5) 213-229.

but with their involvement in agent banking, majority of the respondents were visiting hospitals for medication. The computed paired t-test value of 9.75 is statistically significant at $5 \%$ level of significance; implying that there is a significant difference in the medical seeking behaviour of the respondents before and during the agent banking epochs.

As supplementary analyses, the Foster-Greer-Thorbecke (FGT) index of measuring poverty and the logistic regression model were used. In doing this, the World Bank poverty line of US\$1.9 per day per person was used. This translated to N579.5 per day and N211,5I17.5 per annum at an exchange rate of N305 per dollar (official rate). The FGT indices of the respondents before and during the agent banking in Table 9 .

Table 9: The Foster, Greer and Thorbecke (FGT) Index of Respondents Before and During the Agent Banking

\begin{tabular}{lll}
\hline FGT Index & Before Agent Banking & During Agent Banking \\
\hline $\mathbf{P}_{\mathbf{0}}$ & 0.72 & 0.49 \\
\hline $\mathbf{P}_{\mathbf{1}}$ & 0.53 & 0.29 \\
\hline $\mathbf{P}_{\mathbf{2}}$ & 0.49 & 0.22 \\
\hline
\end{tabular}

Source: Authors' Computation from Field Survey, 2020

The computed indices in Table 9 show the headcount ratio $\left(\mathrm{P}_{0}\right)$ of 0.72 and 0.49 for before and during the agent banking, respectively. The computed headcount ratio which shows the proportion of people below the poverty line suggests that before engaging in agent banking, 72 per cent of the respondents were living below the poverty line of US\$1.9 (N579.5) per day and having got involved in agent banking, 49 per cent of the respondents were living below the poverty line. The implication is that only 23 per cent of the respondents having joined agent banking were lifted above the poverty line, implying them having access to basic needs of food, clothing and shelter as evident in the foregoing multidimensional approach. Also, it is can be seen from Table 9 that, poverty gap $\left(\mathrm{P}_{1}\right)$, which is the mean distance of the income of poor households from the poverty line was 53 per cent before and 29 during the agent banking; while the $\mathrm{P}_{2}$, which measures the severity of poverty was 49 per cent before and 22 per cent during the agent banking.

In order to ascertain whether or not agent banking has the probability of reducing poverty among the agents in Benue State, the logit regression model was estimated and the results are presented in Table 10 


\section{Table 10: Result of Logistic Regression Model}

\begin{tabular}{|c|c|c|c|c|}
\hline Variable & Coefficient & Std. Error & z-Statistic & Prob. \\
\hline Edu & -0.157670 & 0.063188 & -2.495228 & $0.0142 *$ \\
\hline Exab & -0.287305 & 0.048825 & -5.884312 & $0.0024^{*}$ \\
\hline Inab & -0.406603 & 0.149763 & -2.714976 & $0.0250 *$ \\
\hline Vot & -0.343151 & 0.167199 & -2.052350 & 0.0500 \\
\hline Loc & -0.355360 & 0.145866 & -2.985863 & $0.0028 *$ \\
\hline $\mathrm{C}$ & 0.437299 & 0.571514 & -0.765159 & 0.4442 \\
\hline Mean d & 0.58 & \multicolumn{2}{|c|}{ S.D. dependent var } & 0.201274 \\
\hline S.E. of regression & 0.212680 & \multicolumn{2}{|c|}{ Akaike info criterion } & 2.506714 \\
\hline Sum squared resid & 22.53487 & \multicolumn{2}{|c|}{ Schwarz criterion } & 2.727494 \\
\hline Log likelihood & -58.0035 & \multicolumn{2}{|c|}{ Hannan-Quinn criter. } & 1.596410 \\
\hline Restr. log likelihood & -57.8520 & \multicolumn{2}{|c|}{ Avg. log likelihood } & -0.68024 \\
\hline LR statistic (10 df) & 3.697009 & \multirow{2}{*}{\multicolumn{2}{|c|}{ McFadden R-squared }} & 0.437799 \\
\hline Probability(LR stat) & 0.029033 & & & \\
\hline Obs with Dep $=0$ & 98 & \multirow{2}{*}{\multicolumn{2}{|c|}{ Total obs }} & 185 \\
\hline Obs with Dep=1 & 87 & & & \\
\hline
\end{tabular}

The logit regression results have shown that educational level of an agent is inversely related with poverty level and it is statistically significant at $5 \%$ level of significance. This implies that $1 \%$ increase in an agent's educational has the likelihood of reducing poverty of the agent by $0.16 \%$. This may because educated agents are more likely operate the POS better and this enhances their income levels and business operations hence poverty reduction. Also, the experience of the agent about agent banking is negatively related with poverty level. This means that $1 \%$ increase in the experience of the agent about agent banking has the probability of reducing poverty level of the agent by $0.29 \%$. This may be because, having more experience about agent banking will enable the agent to attract more customers both for banking services and sales of items he/she deals in. Furthermore, income from agent banking was found to be inversely related with poverty level, implying that $1 \%$ increase in the income from agent banking has the likelihood of reducing poverty by $0.41 \%$. This suggests that increase in the income levels from the agent banking activities will enable the agents to have access to the basic necessities of shelter, food, clothes and medical services for improved standard of living. Again, the volume of transactions by agents has negative relationship with the poverty level. This suggests that $1 \%$ increase in the volume of transactions by the agents has the probability of reducing poverty by $0.34 \%$. This is because increase in the volume of transactions presupposes increase in income that will lead to poverty reduction. Lastly, the location of the agent was found to be inversely related with the poverty level. For agents who are located in rural areas where there is no presence of banking services are likely to have more customers. This increases their volume of transactions which in turn increases their incomes and welfare.

\section{CONCLUSION AND POLICY IMPLICATIONS}

From the foregoing analysis, it is concluded that engaging in agent banking has the probability of reducing poverty in Benue State which is typically an agrarian state with high poverty incidence as 
Akighir, D. T., \& Jacob, T. T., \& Ateata, A. (2020) Agent Banking And Poverty Reduction In Benue State, Nigeria. Advances in Social Sciences Research Journal, 7(5) 213-229.

well as highly unbanked population. Agent banking in Benue State where only 11 local government areas out of 23 local government areas have the presence of formal banks has the potential of increasing financial inclusion and enhancing financial literacy. With the presence of agent banking in the state, it will enhance business sustainability and facilitate financial transactions. These will increase economic activities and increase employments and reduce poverty.

Given the potentials of agent banking for socio-economic development in the state, it is recommended that financial literacy awareness should be created so that rural population who have long lived unbanked to accept banking services via the agent banking. Also, banks operating in the state should leverage on the opportunity of agent banking to penetrate the rural population with a view to achieving financial inclusion in line with the CBN's revived National Financial Inclusion Strategy (NFIS) which places implementation focus on women, rural areas, youth, Northern Nigeria and MSMEs to achieve 95\% financial inclusion rate by 2024.

\section{References}

Abdullahi A. (1999). Perspective of Poverty Alleviation Programme in Nigeria and the way forward FEAP publication, Abuja.

Ahmed, M. (1993). Choice of a norm of poverty threshold and extent of poverty in Pakistan. The Journal of Development Studies, 12 (1): 12-18.

Ajakaiye, O. (2000). Public Service and the Challenges of Managing Poverty Eradication in Nigeria. A paper presented at the 2003 Retreat for Permanent Secretaries and Directors in the Federal Civil Service of the Federation June 18, at NICON Hilton.

Akeredolu -Ale E.O. (2000). Poverty as a Social Issue: A theoretical note in Poverty in Nigeria. Proceedings of 2000 Annual Conference of the Nigeria Economic Society. University of Ibadan

Akighir, D.T., Ngutsav, A.S. and Asom, S.T. (2011). Assessment of poverty level among rice Millers in Kwande local government area of Benue State, Nigeria, International Journal of Humanities and Social science 1(6): 89-96

Central Bank of Nigeria (CBN) (2017). Guidelines for the regulation of agent banking and agent banking relationships in Nigeria. Publication of the CBN.

Currie, C.V., (2005). Towards a General Theory of Financial Regulation: Predicting, Measuring and Preventing Financial Crises. Working Paper No.132.

Hazell, P. and Hadda, L. (2001). Agricultural research and poverty Reduction. International Food Policy Research Institute Discussion Paper No. 34

Imran, S., Shahnawazi, C. M and Abo, U.H. (2009). The impact of socio-economic and Demographic variables on poverty. A village Study. The Labour Journal of Economics 14(1). 25-42.

Mohammed, A. (2005). Financial Innovation and Poverty Reduction. International Journal of Scientific and Research Publications, 4 (1) : 1-15.

Ngutsav, A.S and Akighir, D.T. (2016). Research Methodology for social and Management Sciences. Makurdi: Climax graphics and Publishers Ltd.

Ogah, D., Okwe, M. \& Adeoye, T. (2015). Agent Banking: Penetrating Markets, Rural Communities for Financial Inclusion Retrieved at https://agencybankingbizsetup.com/ 28/7/2019.

Ogwumuke F.O. (1991). A basic need oriented approach to the development of poverty in Nigeria. Nigerian journal of Economics and Social Studies 33(123):105-120.

Oladeji S.I. \& Abiola A.G. (2000). Poverty alleviation with economic growth Strategy: Prospects and Challenges in contemporary Nigeria. Journal of social development in Africa, 15(.2): 33-54. 
Advances in Social Sciences Research Journal (ASSRJ)

Vol.7, Issue 5, Apr-2020

Oyedeji, I.O. and Adebayo, T. B. (2013). On the derivation of estimators of Foster-Greer-Thorbecke (FGT) poverty indices. CBN Journal of applied Statistics. 4(1): 1-13

Sinkey, J., (1992). Commercial Banks Financial Management. Maxwell MacMillan.

Stiglitz, J. (1981). Financial Market and Development, Oxford Review of Economic Policy, 5(5): 55-68.

Yusuf, S.A, Adesanoya, A.O. and Awotide, D.O. (2008). Assessment of Poverty among Urban farmers in Ibadan metropolis, Nigeria. Journal of Humanities 24(3). 